\title{
Exendin(9-39)amide Is an Antagonist of Glucagon-like Peptide-1(7-36)amide in Humans
}

Jörg Schirra, Kerstin Sturm, Petra Leicht, Rudolf Arnold, Burkhard Göke, and Martin Katschinski

Clinical Research Unit for Gastrointestinal Endocrinology and Department of Gastroenterology and Endocrinology, Philipps University, 35033 Marburg, Germany

\begin{abstract}
The gastrointestinal hormone, glucagon-like peptide-1(736)amide (GLP-1) is released after a meal. The potency of synthetic GLP-1 in stimulating insulin secretion and in inhibiting glucagon secretion indicates the putative physiological function of GLP-1. In vitro, the nonmammalian peptide, exendin(9-39)amide [ex(9-39) $\mathrm{NH}_{2}$ ], is a specific and competitive antagonist of GLP-1. This in vivo study examined the efficacy of ex(9-39) $\mathrm{NH}_{2}$ as an antagonist of exogenous GLP-1 and the physiological role of endogenous GLP-1. Six healthy volunteers underwent 10 experiments in random order. In each experiment, a 30-min period of euglycemia was followed by an intravenous infusion of glucose for $150 \mathrm{~min}$ that established a stable hyperglycemia of $8 \mathrm{mmol} /$ liter. There was a concomitant intravenous infusion of one of the following: (1) saline, (2) GLP-1 (for $60 \mathrm{~min}$ at $0.3 \mathrm{pmol} \cdot \mathrm{kg}^{-1} \cdot \mathrm{min}^{-1}$ that established physiological postprandial plasma levels, and for another $60 \mathrm{~min}$ at $0.9 \mathrm{pmol} \cdot \mathrm{kg}^{-1} \cdot \mathrm{min}^{-1}$ to induce supraphysiological plasma levels), (3-5) ex(9-39) $\mathrm{NH}_{2}$ at 30, 60 , or $300 \mathrm{pmol} \cdot \mathrm{kg}^{-1} \cdot \mathrm{min}^{-1}+\mathrm{GLP}-1,(6-8) \operatorname{ex}(9-39) \mathrm{NH}_{2}$ at 30,60 , or $300 \mathrm{pmol} \cdot \mathrm{kg}^{-1} \cdot \min ^{-1}+$ saline, $(9$ and 10$)$ GIP (glucose-dependent insulinotropic peptide; for $60 \mathrm{~min}$ at $0.8 \mathrm{pmol} \cdot \mathrm{kg}^{-1} \cdot \mathrm{min}^{-1}$, with saline or ex $(9-39) \mathrm{NH}_{2}$ at 300 $\left.\mathrm{pmol} \cdot \mathrm{kg}^{-1} \cdot \min ^{-1}\right)$. Each volunteer received each of these concomitant infusions on separate days. $\operatorname{ex}(9-39) \mathrm{NH}_{2}$ dosedependently reduced the insulinotropic action of GLP-1 with the inhibitory effect declining with increasing doses of GLP-1. ex(9-39) $\mathrm{NH}_{2}$ at $300 \mathrm{pmol} \cdot \mathrm{kg}^{-1} \cdot \mathrm{min}^{-1}$ blocked the insulinotropic effect of physiological doses of GLP-1 and completely antagonized the glucagonostatic effect at both doses of GLP-1. Given alone, this load of ex(9-39) $\mathrm{NH}_{2}$ increased plasma glucagon levels during euglycemia and hyperglycemia. It had no effect on plasma levels of insulin during euglycemia but decreased plasma insulin during hyperglycemia. $\operatorname{ex}(9-39) \mathrm{NH}_{2}$ did not alter GIP-stimulated in-
\end{abstract}

This work was presented in part at the Meeting of the American Gastroenterological Association in May 1997 and published in abstract form (1997. Gastroenterology. 112:A1186).

Address correspondence to Dr. Jörg Schirra, Department of Gastroenterology, Baldingerstr. 1, 35033 Marburg, Germany. Phone: 011-49-6421-282714; FAX: 011-49-6421-288924; E-mail: schirra@ mailer.uni-marburg.de

Received for publication 30 July 1997 and accepted in revised form 21 January 1998

J. Clin. Invest.

(c) The American Society for Clinical Investigation, Inc. 0021-9738/98/04/1421/10 \$2.00

Volume 101, Number 7, April 1998, 1421-1430

http://www.jci.org sulin secretion. These data indicate that in humans, ex(939) $\mathrm{NH}_{2}$ is a potent GLP-1 antagonist without any agonistic properties. The pancreatic A cell is under a tonic inhibitory control of GLP-1. At hyperglycemia, the B cell is under a tonic stimulatory control of GLP-1. (J. Clin. Invest. 1998. 101:1421-1430.) Key words: GLP-1 • exendin(9-39)amide • insulin • glucagon • entero-insulinar axis

\section{Introduction}

The proglucagon-derived glucagon-like peptide-1(7-36)amide (GLP-1) ${ }^{1}$ is a gastrointestinal hormone that is released postprandially from the L cells of the gut (1-3) and exerts a glucose-dependent and direct insulinotropic effect on the pancreatic $B$ cell. It acts via specific receptors, which activate adenylate cyclase (4), and enhances insulin secretion and biosynthesis $(3,5,6)$. In addition, synthetic GLP-1 has been shown in vitro and in vivo to reduce glucagon secretion (7-12). It may also enhance glucose uptake in peripheral tissues (13, 14). These combined effects improve glucose tolerance and are the rationale for evaluating the peptide's therapeutic potential in the treatment of diabetes mellitus $(8,11,15)$. Furthermore, studies in humans indicated an inhibitory role for GLP-1 in the control of gastric emptying and antroduodenal motility $(12,16$, 17), gastric acid secretion (17-19), and satiety (20). Taken together, studies so far indicate that GLP-1 plays a crucial role in integrating postprandial events.

It is a classic and essential requirement in endocrinology to use specific inhibition of the putative endogenous hormone by receptor blockade to evaluate physiological relevance. Recently, a derivative of the nonmammalian peptide, exendin-4, exendin(9-39)amide $\left[\operatorname{ex}(9-39) \mathrm{NH}_{2}\right]$, has been found to act as a specific and competitive antagonist at the GLP-1 receptor (2124). The peptide was isolated from the venom of the lizard Heloderma suspectum and the truncated form, $\operatorname{ex}(9-39) \mathrm{NH}_{2}$, shares 53\% sequence homology to GLP-1(7-36)amide (23). $\operatorname{ex}(9-39) \mathrm{NH}_{2}$ has been applied already in animal experiments. The effect of its intracerebroventricular injection in rats has implicated that GLP-1 acts as a central regulator of satiety as well as of water and salt homeostasis $(25,26)$. Intravenous application of ex(9-39) $\mathrm{NH}_{2}$ in rats has been used to demonstrate that GLP-1 is an important enhancer of postprandial insulin release and, therefore, functions as a true incretin hormone in this species $(27,28)$. Also, in the baboon, antagonism of circulating GLP-1 by $\operatorname{ex}(9-39) \mathrm{NH}_{2}$ impaired the disposal of intragastric glucose, as did immunoneutralization of GLP-1, and

1. Abbreviations used in this paper: $\operatorname{ex}(9-39) \mathrm{NH}_{2}$, exendin(9-39)amide; GIP, glucose-dependent insulinotropic peptide; GLP-1, glucagon-like peptide-1; IR, immunoreactive. 
this was, in part, due to diminished insulin release in the early postprandial phase (29).

So far, an antagonist of GLP-1 has not been investigated in humans. Therefore, this study was designed to assess the efficacy of ex(9-39) $\mathrm{NH}_{2}$ as an antagonist of GLP-1(7-36)amide in men and the endocrine effects of $\operatorname{ex}(9-39) \mathrm{NH}_{2}$ per se. We examined the effects of increasing doses of ex(9-39) $\mathrm{NH}_{2}$ during euglycemia and during physiological hyperglycemia with or without varying doses of exogenous GLP-1(7-36)amide on glucose disposal and on insulin and glucagon release.

\section{Methods}

Subjects. Six healthy male volunteers, 23-27 yr of age and within 5\% of ideal body weight, participated in the study. None of them had a family history of diabetes mellitus or was under any medication. The studies were approved by the Ethical Committee of the Medical Faculty of the Philipps University of Marburg, and all participants provided written informed consent.

Experimental protocol. All studies were performed after an overnight fast. Experiments in individual subjects were separated by intervals of at least $1 \mathrm{wk}$. In the morning of each study, an indwelling catheter was inserted into an antecubital vein for infusion of hormones and glucose. A second catheter was inserted in a retrograde fashion into a dorsal vein of the contralateral hand. This hand was continuously warmed throughout each experiment to exactly $40^{\circ} \mathrm{C}$ by an infrared lamp regulated by a sensor-controlled biothermostat to arterialize the venous blood ("heated hand")

Table I. Experimental Design of the Study

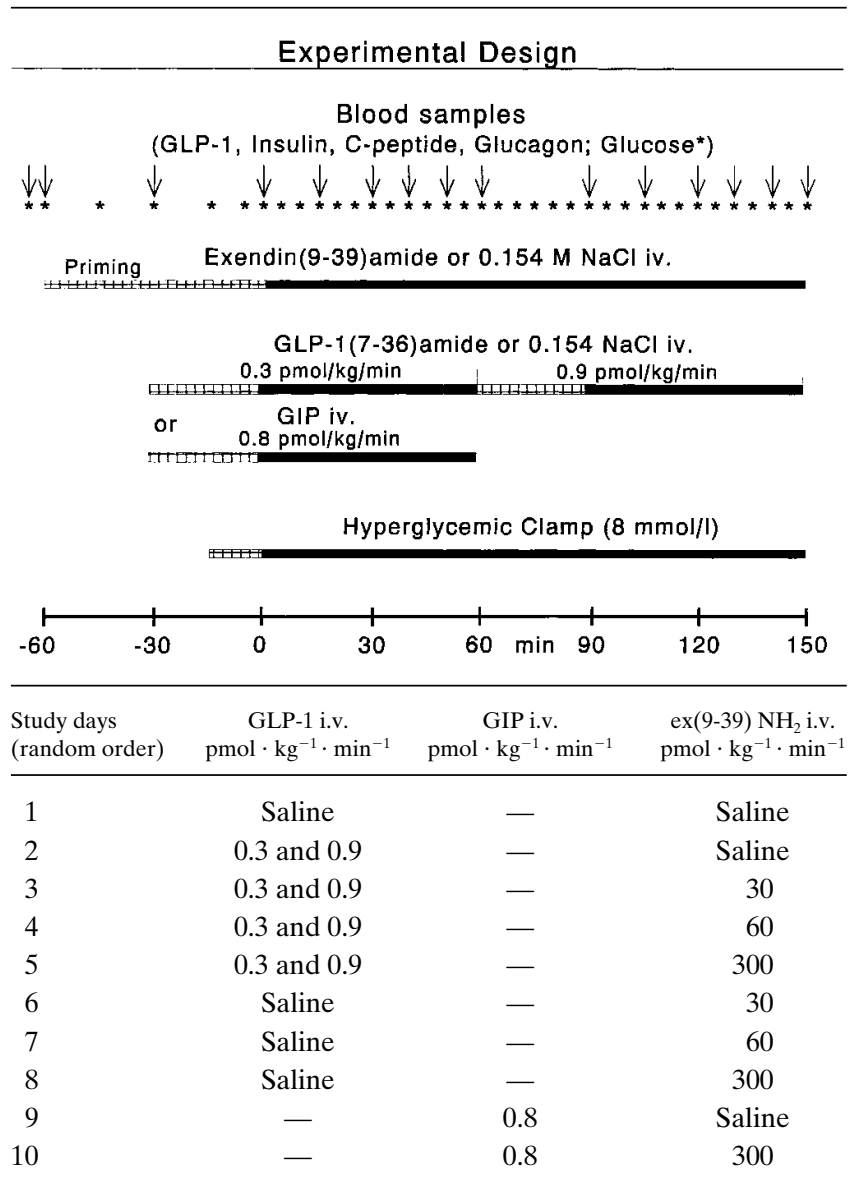

In each experiment, a 30-min period of euglycemia ( -60 to -30 $\mathrm{min}$ ) was followed by adjustment of blood glucose to $8 \mathrm{mmol} /$ liter for 150 min using the glucose clamp technique. This was accomplished by a priming infusion of glucose over $15 \mathrm{~min}$, followed by a variable infusion of a $20 \%$ glucose solution. Infusion rate adjustments were performed according to DeFronzo et al. (30) using a servo-controlled negative feedback formula based on 5-min blood glucose determinations, coupled to a variable speed infusion pump.

Each volunteer underwent 10 experiments in random order. Table I shows the experimental design of the study. On four separate days, GLP-1 was intravenously infused from 0 to $60 \mathrm{~min}$ at $0.3 \mathrm{pmol}$. $\mathrm{kg}^{-1} \cdot \min ^{-1}$ to establish physiological postprandial plasma levels, and from 90 to $150 \mathrm{~min}$ at $0.9 \mathrm{pmol} \cdot \mathrm{kg}^{-1} \cdot \mathrm{min}^{-1}$ to induce supraphysiological plasma levels. Each infusion period was preceded by a priming infusion of GLP-1 over $30 \mathrm{~min}$. In these four experiments with GLP-1, $0.154 \mathrm{M} \mathrm{NaCl}$ and ex(9-39) $\mathrm{NH}_{2}$ at 30,60 , or $300 \mathrm{pmol} \cdot \mathrm{kg}^{-1} \cdot \mathrm{min}^{-1}$ were intravenously infused as background infusions throughout each experiment after a priming infusion over $60 \mathrm{~min}$. On three other days, ex(9-39) $\mathrm{NH}_{2}$ in combination with $0.154 \mathrm{M} \mathrm{NaCl}$ was infused at either 30,60 , or $300 \mathrm{pmol} \cdot \mathrm{kg}^{-1} \cdot \mathrm{min}^{-1}$, respectively. In the experiments with $300 \mathrm{pmol} \cdot \mathrm{kg}^{-1} \cdot \mathrm{min}^{-1} \operatorname{ex}(9-39) \mathrm{NH}_{2} / 0.154 \mathrm{M} \mathrm{NaCl}$, the duration of peptide infusion after the priming period was restricted to $60 \mathrm{~min}$ in order to save peptide. In two further experiments, glucose-dependent insulinotropic peptide (GIP) was infused from 0 to $60 \mathrm{~min}$ at 0.8 pmol $\cdot \mathrm{kg}^{-1} \cdot \mathrm{min}^{-1}$ (priming period from -30 to $0 \mathrm{~min}$ ) to establish physiological postprandial plasma levels, either with background infusion of $0.154 \mathrm{NaCl}$ or ex(9-39) $\mathrm{NH}_{2}$ at $300 \mathrm{pmol} \cdot \mathrm{kg}^{-1} \cdot \mathrm{min}^{-1}$. One study day with infusion of only $0.154 \mathrm{M} \mathrm{NaCl}$ served as control.

Blood samples were taken at $-70,-60,-30,0,15,30,40,50,60$, $90,105,120,130,140$, and $150 \mathrm{~min}$ for determination of the plasma immunoreactivities of GLP-1, GIP, insulin, C-peptide, and glucagon. Blood was collected in ice-chilled EDTA tubes containing 1,000 KIU aprotinin/ml blood and was centrifuged immediately. The plasma was stored at $-20^{\circ} \mathrm{C}$ until assayed. Measurements of glucose in arterialized blood were performed at $-70,-60,-45,-30,-15$, and $-5 \mathrm{~min}$, and in 5-min intervals after the start of the hyperglycemic clamp until the end of each experiment.

Throughout each experiment, pulse rate, blood pressure, and well-being of the volunteers were carefully monitored.

GLP-1(7-36)amide, GIP, and ex(9-39) $\mathrm{NH}_{2}$. Synthetic human GLP-1(7-36)amide, human GIP, and $\operatorname{ex}(9-39) \mathrm{NH}_{2}$ were purchased from Saxon Biochemicals (Hannover, Germany). GLP-1 was delivered as GMP (good manufacturing practice) material of pharmaceutical grade with a peptide content of $88.08 \%$ and a peptide purity $>99 \%$. Peptide contents of GIP and $\operatorname{ex}(9-39) \mathrm{NH}_{2}$ amounted to 70.5 and $79.93 \%$, respectively, and both peptides exhibited a peptide purity $>99 \%$. HPLC showed a single peak for GLP-1(7-36)amide, GIP, and ex $(9-39) \mathrm{NH}_{2}$, respectively. All peptides were dissolved in $1 \%$ HSA, filtered through $0.2-\mu \mathrm{m}$ nitrocellulose filters, and then stored at $-70^{\circ} \mathrm{C}$. HPLC after sterile filtration performed for all three peptides showed single peaks, clearly separated from the HSA peak and confirmed a peptide recovery of $100 \%$ compared with the peptide solution before filtration. Samples were tested for pyrogens and bacterial growth, and no contamination with bacterials or endotoxins was detected. Dose calculations were based on peptide contents of preparations.

Determinations and assays. Blood glucose concentrations were measured by the glucose oxidase method using a glucose analyzer (YSI 1500 G; Schlag Co., Bergisch-Gladbach, Germany). Plasma immunoreactivities of insulin, C-peptide, GIP, and glucagon were analyzed by commercially available radioimmunoassay kits (Biermann, Bad Nauheim, Germany). Immunoreactive (IR) GLP-1 was measured using the specific polyclonal antibody GA 1178 (Affinity Research, Nottingham, United Kingdom) as described previously (2). Immunoreactivities were extracted from plasma samples on C-18 cartridges using acetonitrile for elution of samples. The detection limit of the assay was $0.25 \mathrm{pmol} / \mathrm{liter}$. The antiserum did not cross-react with ex(9-39) $\mathrm{NH}_{2}$, GIP, pancreatic glucagon, glicentin, oxyntomodulin, or 


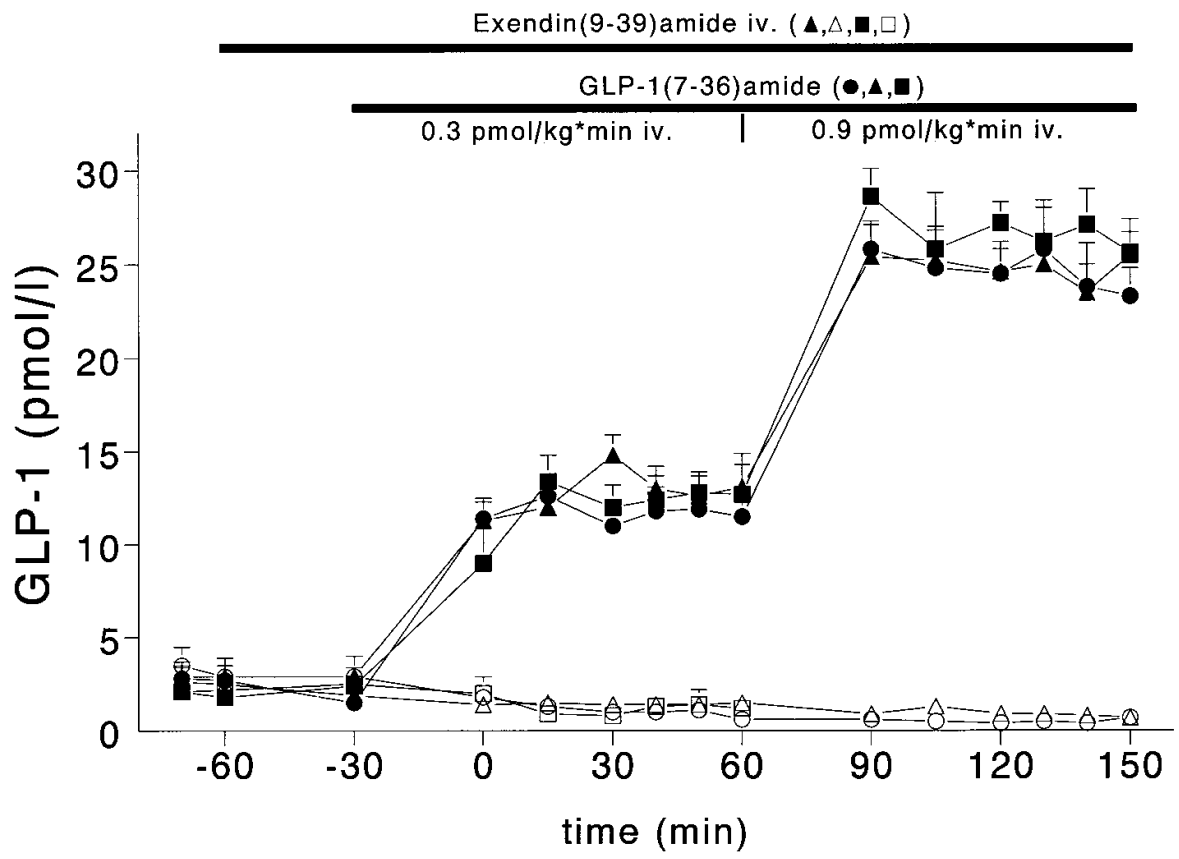

-o- Saline iv.

$$
-\mathbf{A}-\mathrm{GLP}-1+\operatorname{Ex}(9-39) \mathrm{NH}_{2} 30
$$$$
-\Delta-\text { Saline }+\operatorname{Ex}(9-39) \mathrm{NH}_{2} 30
$$$$
-\bullet \text { GLP-1 iv. }
$$$$
- \text { - GLP-1 }+\operatorname{Ex}(9-39) \mathrm{NH}_{2} 300
$$$$
-\square-\text { Saline }+\operatorname{Ex}(9-39) \mathrm{NH}_{2} 300
$$

Figure 1. Immunoreactivities of GLP-1 in response to single or combined intravenous infusions of GLP-1(7-36)amide at 0.3 and 0.9 $\mathrm{pmol} \cdot \mathrm{kg}^{-1} \cdot \mathrm{min}^{-1}$ and $\operatorname{ex}(9-39) \mathrm{NH}_{2}$ at 30 or $300 \mathrm{pmol} \cdot \mathrm{kg}^{-1} \cdot \mathrm{min}^{-1}$ in six healthy volunteers. Mean \pm SEM. For statistical analysis, see Tables II and III.
GLP-2. Intra- and interassay coefficients of variation were 3.8 and $10.9 \%$, respectively.

Statistical analysis. All values were expressed as mean \pm SEM. Time courses of plasma hormones, glucose, and glucose infusion rate were represented by actual or incremental values over basal. Basal levels were determined as the mean of the two first values at the start of each experiment ( -70 and $-60 \mathrm{~min}$ ). For low and high dose GLP-1, the effects of the different background infusions on plasma hormones, blood glucose, and glucose infusion rate were analyzed separately. Here, mean incremental plasma hormone and blood glucose levels over basal as well as mean glucose infusion rates during the last $45 \mathrm{~min}$ of each infusion period of GLP-1 were used for evaluation.

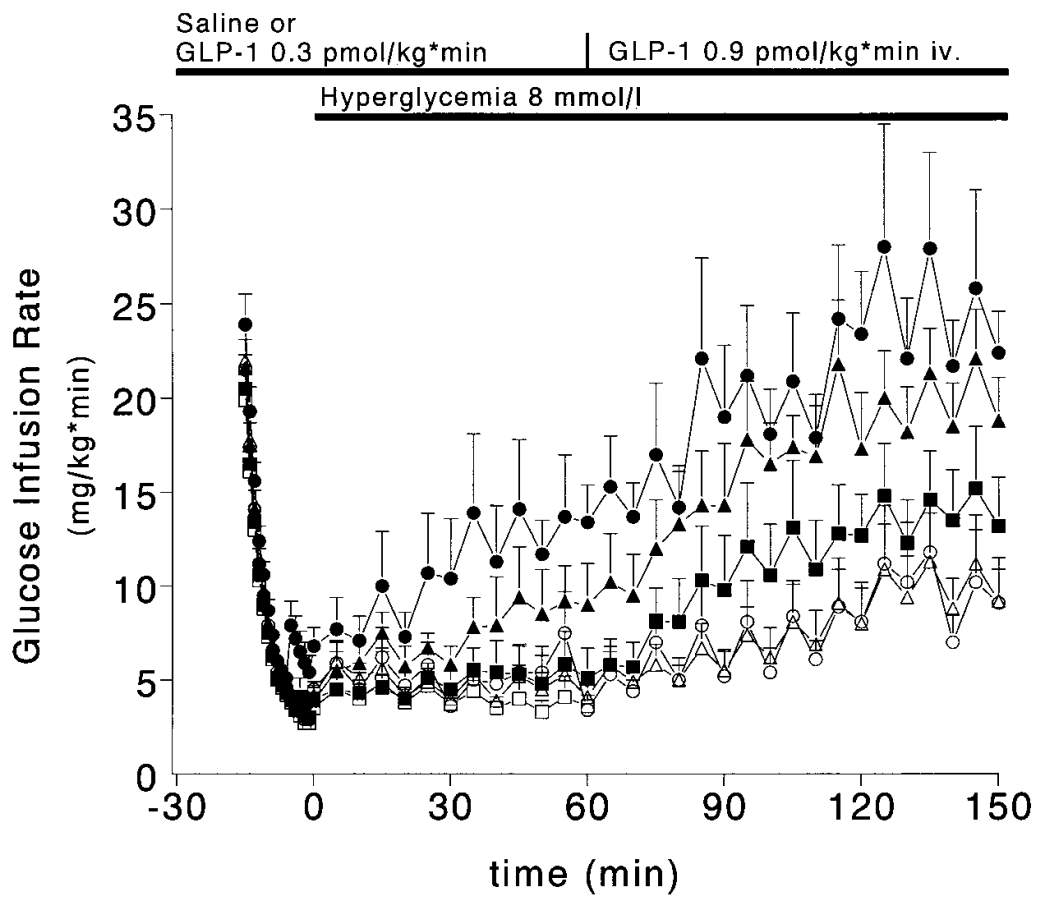

$-\mathrm{O}-$ Saline iv.

$-\mathbf{A L P}-1+\mathrm{Ex}(9-39) \mathrm{NH}_{2} 30$

$-\triangle-$ Saline $+\operatorname{Ex}(9-39) \mathrm{NH}_{2} 30$

- - GLP-1 iv. $-\square-$ Saline + Ex(9-39) $\mathrm{NH}_{2} 300$
Figure 2. Infusion rates of exogenous glucose during glucose clamp at $8 \mathrm{mmol} /$ liter in six healthy volunteers in response to single or combined intravenous infusions of GLP-1(7-36)amide at 0.3 and $0.9 \mathrm{pmol}$. $\mathrm{kg}^{-1} \cdot \min ^{-1}$ and ex(9-39) $\mathrm{NH}_{2}$ at 30 or 300 $\mathrm{pmol} \cdot \mathrm{kg}^{-1} \cdot \mathrm{min}^{-1}$. Mean $\pm \mathrm{SEM}$. For statistical analysis, see Tables II and III. 
Table II. Effect of Graded Doses of Intravenous ex(9-39) $\mathrm{NH}_{2}$ on Consumption of Exogenous Glucose, Blood Glucose Levels, and Plasma Immunoreactivities of GLP-1, Insulin, C-Peptide, and Glucagon against Intravenous Background Infusions of Saline or Postprandial Physiological Doses of GLP-1 or GIP during the First Infusion Period (0-60 min) of the Hyperglycemic Clamp (8 mol/liter) in Healthy Subjects

\begin{tabular}{|c|c|c|c|c|c|c|}
\hline Combination of intravenous infusions & Blood glucose & IR-GLP-1* & Glucose infusion rate & IR-Insulin* & IR-C-peptide* & IR-Glucagon* \\
\hline & mmol/liter & $\mathrm{pmol} /$ liter & $\mathrm{mg} / \mathrm{kg} \cdot \min$ & mU/liter & $n g / m l$ & $p g / m l$ \\
\hline \multicolumn{7}{|l|}{ Saline i.v. } \\
\hline Saline + saline & $8.0 \pm 0.03$ & $-2.2 \pm 0.6$ & $5.2 \pm 1.0$ & $15.0 \pm 4.2$ & $2.2 \pm 0.4$ & $-17.2 \pm 1.7$ \\
\hline Saline $+\operatorname{ex}(9-39) \mathrm{NH}_{2} 30$ & $8.0 \pm 0.07$ & $-1.2 \pm 0.5$ & $4.7 \pm 0.4$ & $15.5 \pm 3.1$ & $2.1 \pm 0.3$ & $-14.5 \pm 4.2$ \\
\hline Saline $+\operatorname{ex}(9-39) \mathrm{NH}_{2} 60$ & $8.0 \pm 0.03$ & $-1.9 \pm 0.6$ & $4.5 \pm 0.4$ & $14.9 \pm 5.0$ & $2.7 \pm 0.7$ & $-9.3 \pm 4.0$ \\
\hline Saline $+\operatorname{ex}(9-39) \mathrm{NH}_{2} 300$ & $8.0 \pm 0.03$ & $-1.0 \pm 0.2$ & $4.0 \pm 0.8^{\ddagger}$ & $8.6 \pm 1.5^{\ddagger}$ & $1.8 \pm 0.3^{\ddagger}$ & $-2.0 \pm 4.7^{+}$ \\
\hline \multicolumn{7}{|l|}{ GLP-1 $0.3 \mathrm{pmol} \cdot \mathrm{kg}^{-1} \cdot \min ^{-1}$} \\
\hline GLP-1 + saline & $7.9 \pm 0.06$ & $8.9 \pm 1.1^{\ddagger}$ & $11.7 \pm 2.7^{\ddagger}$ & $54.7 \pm 17.1^{\ddagger}$ & $6.7 \pm 1.0^{\ddagger}$ & $-23.0 \pm 2.6^{\ddagger}$ \\
\hline GLP-1 $+\operatorname{ex}(9-39) \mathrm{NH}_{2} 30$ & $7.9 \pm 0.06$ & $10.2 \pm 1.0^{\ddagger}$ & $7.8 \pm 1.6^{\ddagger \S}$ & $42.1 \pm 19.0^{\ddagger}$ & $5.0 \pm 1.2^{\ddagger \S}$ & $-15.7 \pm 3.4$ \\
\hline GLP-1 $+\operatorname{ex}(9-39) \mathrm{NH}_{2} 60$ & $7.8 \pm 0.07$ & $11.8 \pm 0.8^{\ddagger}$ & $8.3 \pm 1.9^{\ddagger \S}$ & $38.0 \pm 13.8^{\ddagger \S}$ & $4.6 \pm 0.9^{\ddagger \S \|}$ & $-16.2 \pm 5.0$ \\
\hline GLP-1 + ex(9-39) $\mathrm{NH}_{2} 300$ & $8.0 \pm 0.08$ & $10.6 \pm 0.6^{\ddagger}$ & $5.0 \pm 1.2^{\S \|}$ & $22.0 \pm 8.2^{\S}$ & $3.1 \pm 0.5^{\S \|}$ & $-7.6 \pm 3.2^{\ddagger \S}$ \\
\hline \multicolumn{7}{|l|}{ GIP-1 $0.8 \mathrm{pmol} \cdot \mathrm{kg}^{-1} \cdot \mathrm{min}^{-1}$} \\
\hline GIP + saline & $8.0 \pm 0.07$ & $-1.1 \pm 0.5$ & $7.4 \pm 0.7^{\ddagger \S}$ & $33.5 \pm 10.2^{\ddagger \S}$ & $3.8 \pm 1.0^{\ddagger \S}$ & $-12.9 \pm 3.2^{\S}$ \\
\hline $\mathrm{GIP}+\operatorname{ex}(9-39) \mathrm{NH}_{2} 300$ & $7.9 \pm 0.09$ & $-1.4 \pm 0.8$ & $7.3 \pm 0.8^{\ddagger \S}$ & $31.9 \pm 9.9^{\ddagger \S}$ & $3.6 \pm 1.1^{\ddagger \S}$ & $-5.0 \pm 2.8^{\ddagger \S \pi}$ \\
\hline
\end{tabular}

Mean \pm SEM of actual values during the last $45 \mathrm{~min}$ of the first infusion period $(15-60 \mathrm{~min}) . n=6$. * Mean increment in actual values from basal \pm SEM. ${ }^{\ddagger} P<0.05$ vs. saline/saline; ${ }^{\S} P<0.05$ vs. GLP-1/saline; ${ }^{\|} P<0.05$ vs. GLP-1/ex(9-39) $\mathrm{NH}_{2} 30 ;{ }^{\pi} P<0.05$ vs. GIP/saline. Doses of ex $(9-39)-$ $\mathrm{NH}_{2}$ represent $\mathrm{pmol} \cdot \mathrm{kg}^{-1} \cdot \mathrm{min}^{-1}$. Keypoints are indicated in bold letters.

All samples were first tested for normality of distribution by the Kolmogoroff-Smirnoff test. Differences between experimental sets were analyzed by one-way repeated-measures ANOVA. When this analysis indicated different responses, a Student-Newman-Keuls multicomparison test was performed. Differences were considered significant at $P<0.05$.

\section{Results}

The intravenous infusions of $\operatorname{ex}(9-39) \mathrm{NH}_{2}$ were well tolerated in all volunteers, even upon repeated administrations.
Pooling all experiments, basal blood glucose was $4.5 \pm 0.04$ $\mathrm{mmol} /$ liter. During the $150 \mathrm{~min}$ of controlled hyperglycemia, blood glucose concentrations amounted to $7.9 \pm 0.01 \mathrm{mmol} / \mathrm{li}-$ ter. They were stably maintained throughout this period with a variation coefficient of $4.5 \pm 0.3 \%$.

Basal GLP-1 levels averaged 2.8 \pm 0.2 pmol/liter (Fig. 1). With intravenous infusions of GLP-1 at 0.3 and $0.9 \mathrm{pmol} \cdot \mathrm{kg}^{-1}$. $\min ^{-1}$, plasma levels of GLP-1 dose-dependently increased. Stable plasma levels were reached within $30 \mathrm{~min}$ by infusion of both the low $(13.0 \pm 0.5 \mathrm{pmol} / \mathrm{liter})$ and the high $(25.9 \pm 0.8$ pmol/liter) load of GLP-1. Immunoreactivities of GLP-1 were

Table III. Effect of Graded Doses of Intravenous ex(9-39) $\mathrm{NH}_{2}$ on Consumption of Exogenous Glucose, Blood Glucose Levels, and Plasma Immunoreactivities of GLP-1, Insulin, C-Peptide, and Glucagon against Intravenous Background Infusions of Saline or a Supraphysiological Dose of GLP-1 during the Second Infusion Period (90-150 min) of the Hyperglycemic Clamp (8 mol/liter) in Healthy Subjects

\begin{tabular}{|c|c|c|c|c|c|c|}
\hline Combination of intravenous infusions & Blood glucose & IR-GLP-1* & Glucose infusion rate & IR-Insulin* & IR-C-Peptide* & IR-Glucagon* \\
\hline & mmol/liter & pmol/liter & $\mathrm{mg} / \mathrm{kg} \cdot \min$ & mU/liter & $n g / m l$ & $\mathrm{pg} / \mathrm{ml}$ \\
\hline \multicolumn{7}{|l|}{ Saline i.v. } \\
\hline Saline + saline & $7.9 \pm 0.02$ & $-2.7 \pm 0.8$ & $9.1 \pm 2.2$ & $26.9 \pm 7.2$ & $3.9 \pm 0.6$ & $-18.6 \pm 3.4$ \\
\hline Saline $+\operatorname{ex}(9-39) \mathrm{NH}_{2} 30$ & $7.9 \pm 0.03$ & $-1.8 \pm 0.6$ & $9.3 \pm 2.1$ & $27.8 \pm 6.8$ & $3.9 \pm 0.7$ & $-19.6 \pm 4.5$ \\
\hline Saline $+\operatorname{ex}(9-39) \mathrm{NH}_{2} 60$ & $7.9 \pm 0.04$ & $-3.6 \pm 0.7$ & $8.8 \pm 2.4$ & $26.1 \pm 7.6$ & $3.6 \pm 0.7$ & $-13.2 \pm 3.4$ \\
\hline \multicolumn{7}{|l|}{ GLP-1 $0.9 \mathrm{pmol} \cdot \mathrm{kg}^{-1} \cdot \mathrm{min}^{-1}$} \\
\hline GLP-1 + saline & $8.0 \pm 0.05$ & $21.7 \pm 1.7^{\frac{1}{+}}$ & $23.5 \pm 3.3^{\ddagger}$ & $402.6 \pm 129.5^{\ddagger}$ & $19.1 \pm 3.8^{\ddagger}$ & $-27.5 \pm 3.8^{\ddagger}$ \\
\hline GLP-1 + ex(9-39) $\mathrm{NH}_{2} 30$ & $8.0 \pm 0.02$ & $21.8 \pm 1.3^{\ddagger}$ & $19.3 \pm 2.3^{\ddagger \S}$ & $300.1 \pm 142.2^{\ddagger \S}$ & $13.9 \pm 3.4^{\ddagger \S}$ & $-21.0 \pm 3.2$ \\
\hline GLP-1 + ex(9-39) $\mathrm{NH}_{2} 60$ & $7.9 \pm 0.01$ & $25.1 \pm 1.3^{\ddagger}$ & $19.4 \pm 2.6^{\ddagger \S}$ & $249.4 \pm 106.4^{\ddagger \S}$ & $12.4 \pm 3.1^{\ddagger \S}$ & $-20.5 \pm 5.5$ \\
\hline GLP-1 + ex(9-39) $\mathrm{NH}_{2} 300$ & $7.9 \pm 0.04$ & $24.4 \pm 1.3^{\ddagger}$ & $13.3 \pm 2.7^{\ddagger \S} \|$ & 97.1 $\pm 42.5^{\ddagger \S \|}$ & $\mathbf{6 . 6} \pm \mathbf{0 . 5} \mathbf{5}^{\ddagger \S} \|$ & $-16.1 \pm 3.7^{\S}$ \\
\hline
\end{tabular}

Mean \pm SEM of actual values during the last 45 min of the second infusion period (105-150 min). $n=6 . *$ Mean increment in actual values from basal \pm SEM. ${ }^{\ddagger} P<0.05$ vs. saline/saline; ${ }^{\S} P<0.05$ vs. GLP-1/saline; ${ }^{\|} P<0.05$ vs. GLP-1/ex $(9-39) \mathrm{NH}_{2} 30$. Doses of ex $(9-39) \mathrm{NH} \mathrm{H}_{2}$ represent pmol $\cdot \mathrm{kg}^{-1}$. $\min ^{-1}$. Keypoints are indicated in bold letters. 


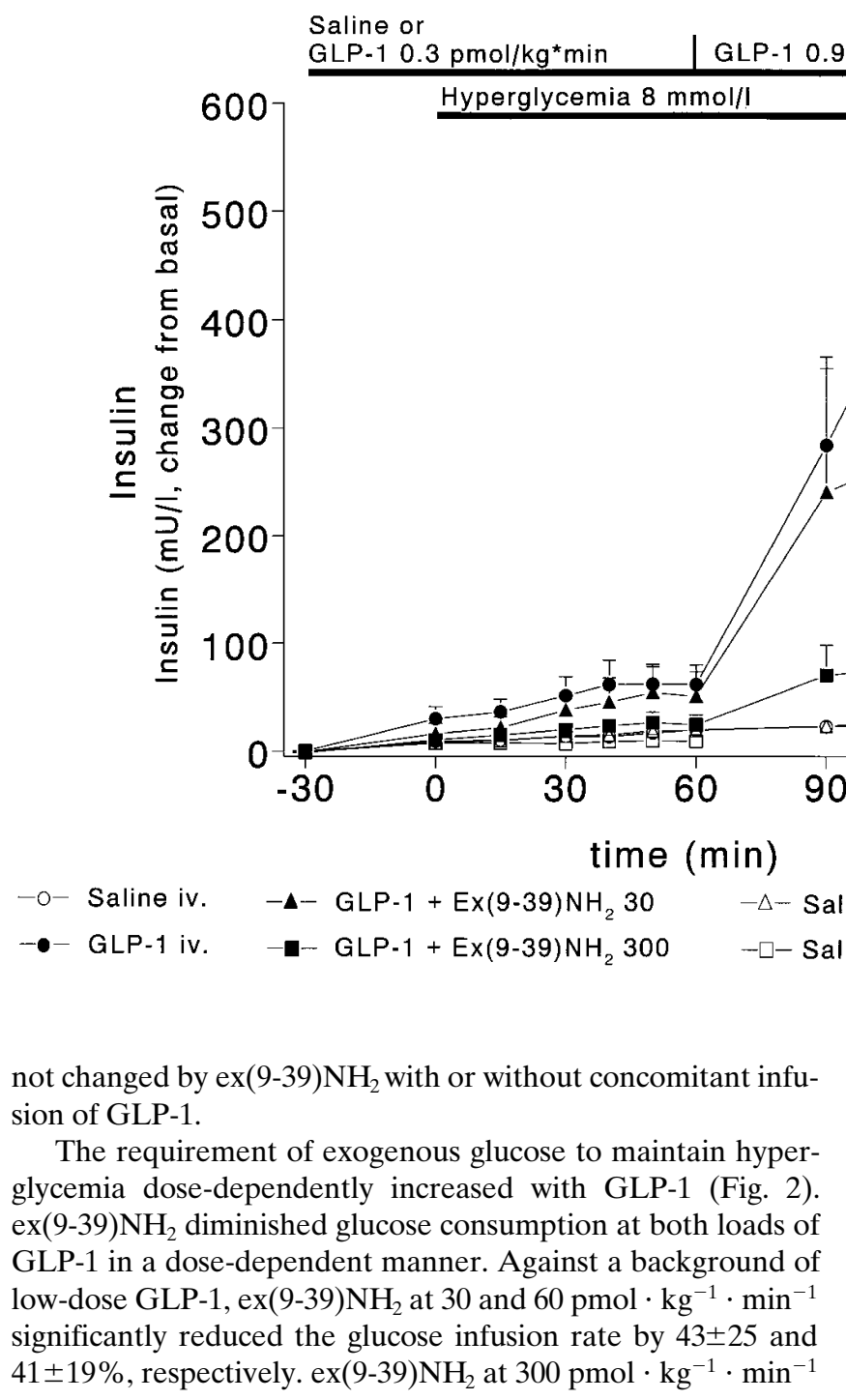

totally abolished the elevated demand for exogenous glucose (reduction by $105 \pm 10 \%$, Table II, see Fig. $6 \mathrm{~A}$ ). With the high load of GLP-1, glucose consumption was also substantially reduced by increasing loads of ex $(9-39) \mathrm{NH}_{2}$ (reduction by $25 \pm 12,26 \pm 9$, and $70 \pm 6 \%$ with 30,60 , and $300 \mathrm{pmol} \cdot \mathrm{kg}^{-1}$. $\min ^{-1}$, respectively). Still, it remained significantly elevated compared with saline control, even at the highest load of ex (9-39) $\mathrm{NH}_{2}$ (Table III, see Fig. 6 B).

Pooling all experiments, basal levels of IR-insulin and IR-

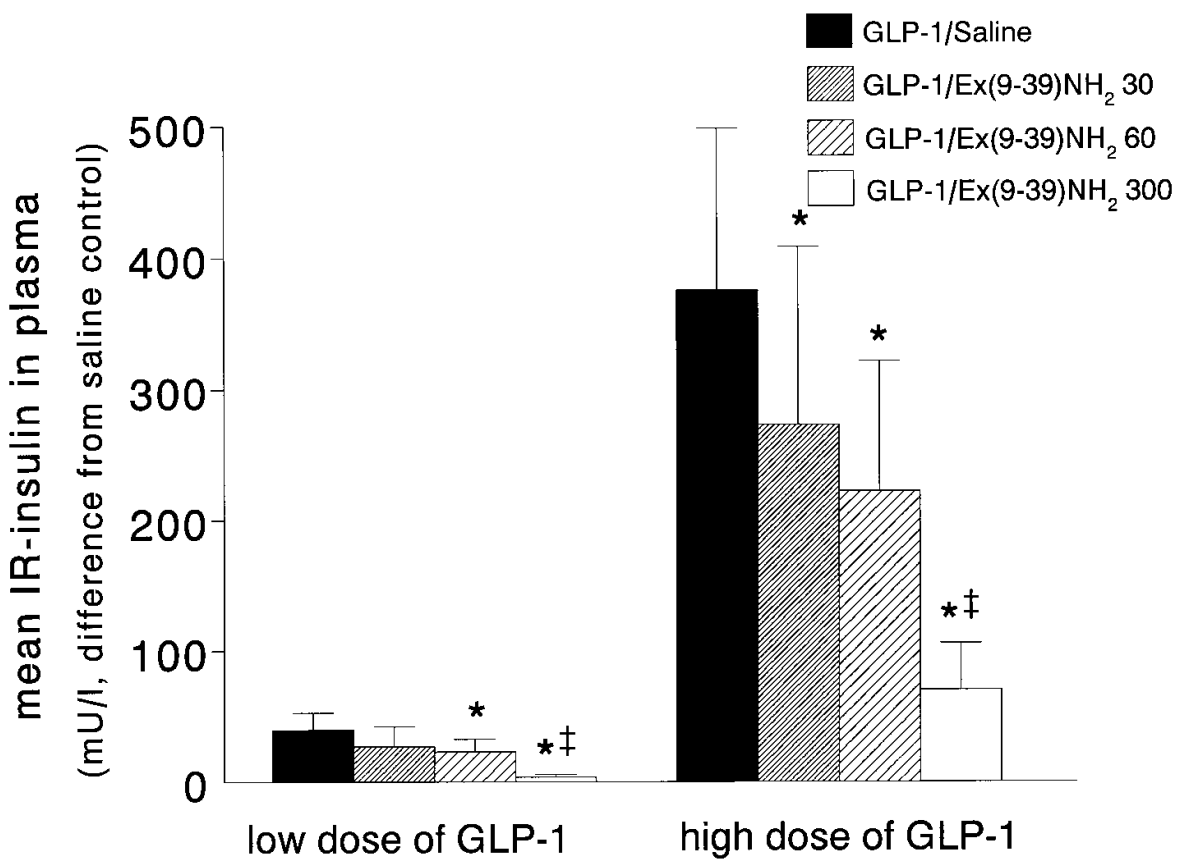

Figure 4. Effect of intravenous infusions of graded doses of ex(9-39) $\mathrm{NH}_{2}(30,60$, and $\left.300 \mathrm{pmol} \cdot \mathrm{kg}^{-1} \cdot \min ^{-1}\right)$ on incremental IR-insulin with intravenous infusions of GLP-1(7-36)amide at 0.3 (low dose) or $0.9 \mathrm{pmol} \cdot \mathrm{kg}^{-1} \cdot \mathrm{min}^{-1}$ (high dose) in six healthy volunteers. Data are shown as differences from saline control. Mean \pm SEM. $* P<0.05$ indicating significant differences compared with GLP-1(7-36)amide/saline. ${ }^{\ddagger} P<0.05$ indicating significant differences compared with GLP-1(7-36)amide/ ex(9-39) $\mathrm{NH}_{2} 60$. 


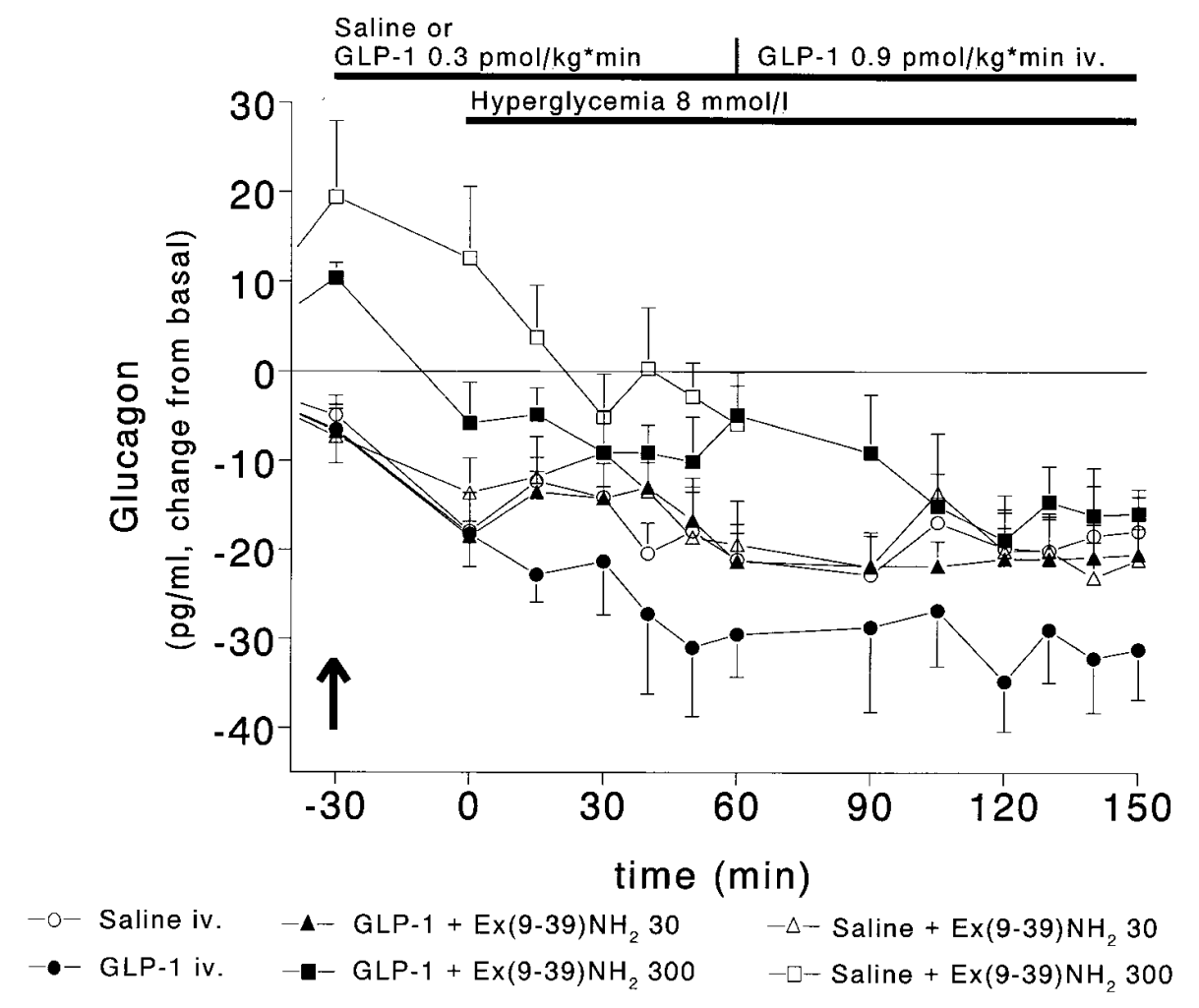

Figure 5. Immunoreactivities of glucagon over basal, i.e., mean of values at -70 and $-60 \mathrm{~min}$, at euglycemia $(-30 \mathrm{~min})$ and during hyperglycemia at $8 \mathrm{mmol} /$ liter in six healthy volunteers. Shown are responses to single or combined infusions of GLP-1(7-36)amide at 0.3 and $0.9 \mathrm{pmol} \cdot \mathrm{kg}^{-1}$. $\mathrm{min}^{-1}$ and ex(9-39) $\mathrm{NH}_{2}$ at 30 or $300 \mathrm{pmol}$. $\mathrm{kg}^{-1} \cdot \min ^{-1}$. Mean \pm SEM. With ex(9-39)$\mathrm{NH}_{2}$ at $300 \mathrm{pmol} \cdot \mathrm{kg}^{-1} \cdot \mathrm{min}^{-1}$ during euglycemia (white and black squares, -30 min), glucagon plasma levels were significantly elevated compared with saline or the low dose of ex(9-39) $\mathrm{NH}_{2}(P<0.05$, arrow $)$. See text for further explanation. For statistical analysis of IR-glucagon during hyperglycemia, see Tables II and III.
C-peptide averaged $4.2 \pm 0.3 \mathrm{mU} /$ liter and $1.2 \pm 0.1 \mathrm{ng} / \mathrm{ml}$, respectively. The plasma levels of IR-insulin (Fig. 3) strongly paralleled those of IR-C-peptide. IR-insulin was dose-dependently raised to mean plasma levels of $54.7 \pm 17.1 \mathrm{mU} / \mathrm{liter}$ at the low and $402.6 \pm 129.5 \mathrm{mU} / \mathrm{liter}$ at the high load of GLP-1, respectively. ex(9-39) $\mathrm{NH}_{2}$ coinfused with GLP-1 inhibited dose-dependently this insulin releasing effect of GLP-1. Coinfusion of the highest dose of $\operatorname{ex}(9-39) \mathrm{NH}_{2}$ reduced plasma insulin obtained with the low dose of GLP-1 by $95 \pm 10 \%$. Then, the resultant plasma levels of insulin corresponded to saline control (Fig. 4 and Table II). In contrast, plasma insulin with high dose GLP-1 was reduced at the highest dose of ex(939) $\mathrm{NH}_{2}$ by $84 \pm 6 \%$. However, these levels still resided above those under saline control $(P<0.05$, Fig. 4 and Table III).

Basal levels of glucagon amounted to $57.8 \pm 3.2 \mathrm{pg} / \mathrm{ml}$. Infusion of exogenous glucose in the hyperglycemic clamp reduced IR-glucagon. Both loads of GLP-1 further significantly decreased IR-glucagon (Fig. 5 and Tables II and III). Coinfused with GLP-1, ex(9-39) $\mathrm{NH}_{2}$ dose-dependently blocked the glucagon lowering action of GLP-1. Even the lowest dose of ex(939) $\mathrm{NH}_{2}\left(30 \mathrm{pmol} \cdot \mathrm{kg}^{-1} \cdot \mathrm{min}^{-1}\right)$ was sufficient to completely antagonize the diminution of IR-glucagon induced by both loads of GLP-1. Coinfusion of $\operatorname{ex}(9-39) \mathrm{NH}_{2}$ at $300 \mathrm{pmol} \cdot \mathrm{kg}^{-1}$. $\mathrm{min}^{-1}$ and low dose GLP-1 not only blocked the effect of GLP-1, but significantly raised plasma glucagon levels compared with saline control (Table II and Fig. $6 A$ ).

At euglycemia, infusion of ex(9-39) $\mathrm{NH}_{2}$ at $300 \mathrm{pmol} \cdot \mathrm{kg}^{-1}$. $\mathrm{min}^{-1}$ significantly raised basal plasma glucagon levels by $12.9 \pm 3.5 \mathrm{pg} / \mathrm{ml}(P<0.05$ vs. saline control, Figs. 5 and 7$)$. This effect of the highest load of ex(9-39) $\mathrm{NH}_{2}$ was accompanied by an increase of blood glucose from basal levels of $4.5 \pm 0.08$ to $4.9 \pm 0.07 \mathrm{mmol} / \mathrm{liter}(P<0.05$, Fig. 7). Plasma insulin remained unchanged with $\operatorname{ex}(9-39) \mathrm{NH}_{2}$ in the euglycemic state.
During the hyperglycemic clamp, ex(9-39) $\mathrm{NH}_{2}$ dose-dependently enhanced plasma glucagon. This increase of IR-glucagon was significant at the highest dose of $\operatorname{ex}(9-39) \mathrm{NH}_{2}$ (Table II and Fig. $6 \mathrm{~A}$ ). It already became evident at euglycemia and persisted with hyperglycemia. Remarkably, hyperglycemia still reduced IR-glucagon against a background of $\operatorname{ex}(9-39) \mathrm{NH}_{2}$ (Fig. 5). In parallel to the elevated plasma glucagon, glucose requirement maintaining hyperglycemia was dose-dependently reduced by ex(9-39) $\mathrm{NH}_{2}\left[P<0.05\right.$ for ex(9-39) $\mathrm{NH}_{2} 300 \mathrm{pmol}$. $\mathrm{kg}^{-1} \cdot \mathrm{min}^{-1}$ vs. saline control; Table II]. The increase of insulin during hyperglycemia was significantly inhibited by ex(939) $\mathrm{NH}_{2}$ at the highest dose (Table II).

With intravenous infusion of GIP, physiological plasma levels were achieved $(2,11)$. Plasma IR-GIP upon GIP infusion rose from basal levels of $150.6 \pm 25.2 \mathrm{pg} / \mathrm{ml}$ to a steady state of $616.1 \pm 27.3 \mathrm{pg} / \mathrm{ml}$ with saline, and from $176.0 \pm 35.6$ to $591.2 \pm 27.3 \mathrm{pg} / \mathrm{ml}$ at the highest dose of $\operatorname{ex}(9-39) \mathrm{NH}_{2}$ (differences not significant). Compared with saline, GIP significantly stimulated glucose consumption as well as release of insulin and C-peptide. The insulinotropic effects of GIP were significantly smaller compared with GLP-1 (Table II). Coadministration of ex(9-39) $\mathrm{NH}_{2}$ at $300 \mathrm{pmol} \cdot \mathrm{kg}^{-1} \cdot \mathrm{min}^{-1}$ affected neither insulin and C-peptide responses to GIP nor the infusion rate of exogenous glucose during hyperglycemia. GIP did not influence plasma levels of glucagon. Coinfusion of $\operatorname{ex}(9-39) \mathrm{NH}_{2}$ and GIP caused a significant increase of plasma glucagon compared with the effect of GIP alone.

\section{Discussion}

This study introduces ex(9-39) $\mathrm{NH}_{2}$ as an antagonist of GLP-1 in human. So far, ex(9-39) $\mathrm{NH}_{2}$ was established in vitro or in animal models as a competitive antagonist at the GLP-1 recep- 


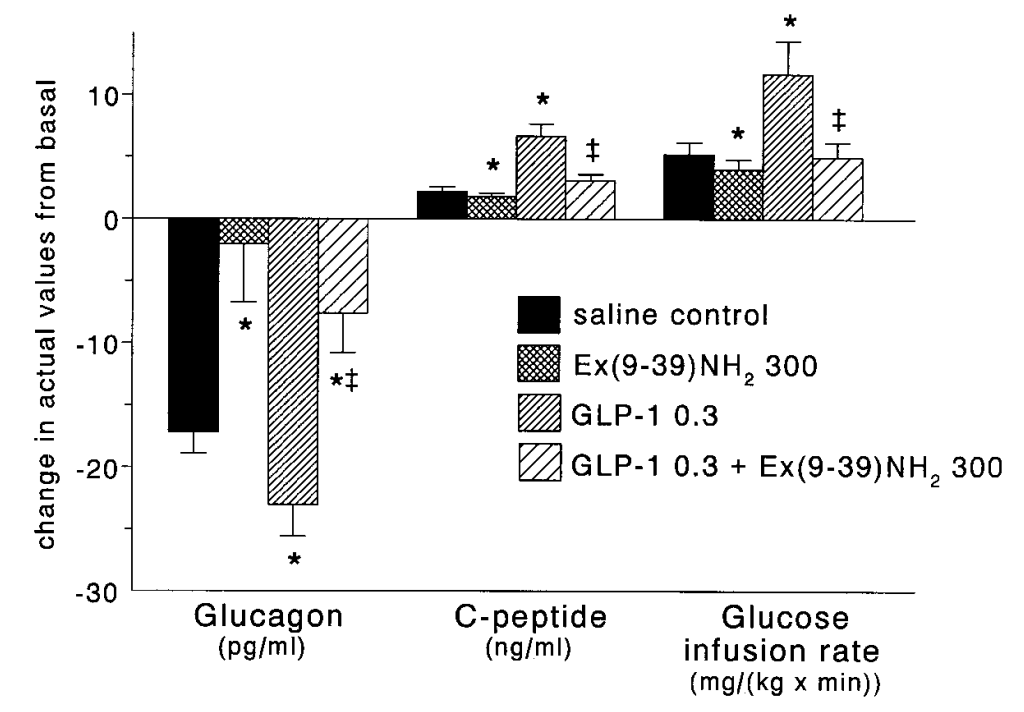

B

Effects of IV GLP-1, supraphysiological dose, with or without exendin(9-39)amide

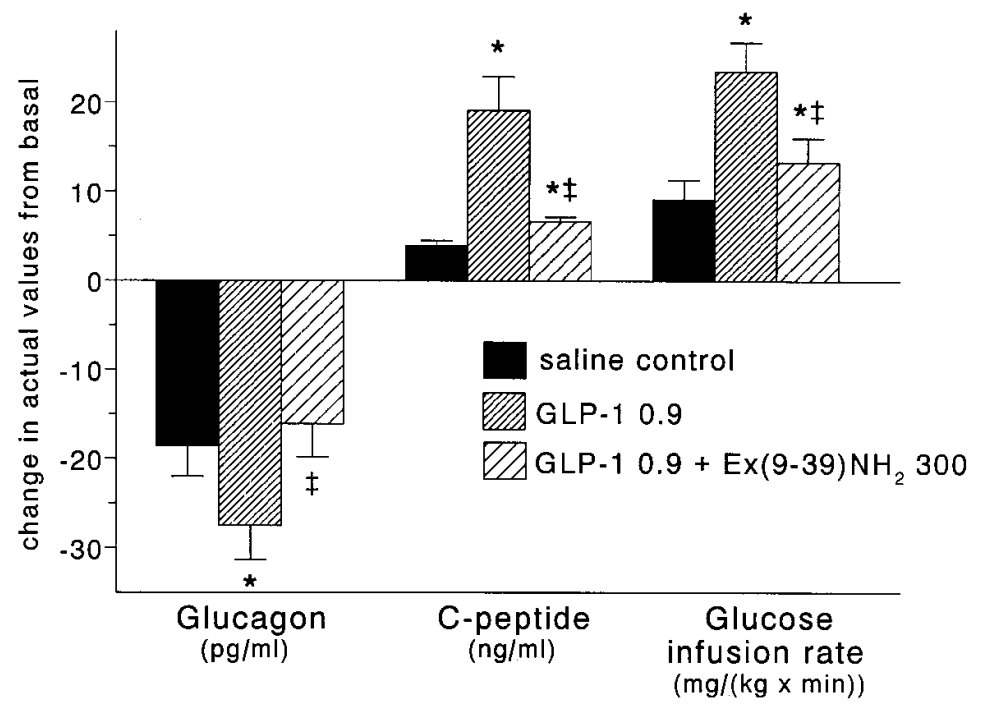

Figure 6. Effects of intravenous infusions of GLP1(7-36)amide at $0.3(A)$ and $0.9 \mathrm{pmol} \cdot \mathrm{kg}^{-1} \cdot \mathrm{min}^{-1}$ (B) and ex(9-39) $\mathrm{NH}_{2}$ at $300 \mathrm{pmol} \cdot \mathrm{kg}^{-1} \cdot \mathrm{min}^{-1}$ during hyperglycemia on the incremental response over basal, i.e., mean of values at -70 and $-60 \mathrm{~min}$, of IR-glucagon and IR-C-peptide, and on the infusion rate of exogenous glucose during glucose clamp at $8 \mathrm{mmol} /$ liter in six healthy volunteers. Mean \pm SEM of individual means during the last $45 \mathrm{~min}$ of the first (15-60 $\mathrm{min}, A)$ and second (105-150 min, $B$ ) infusion period. $* P<0.05$ indicating significant differences compared with saline control. ${ }^{\ddagger} P<0.05$ indicating significant differences compared with GLP-1(7-36)amide. See Tables II and III for further details.

tor $(21,23,27-29)$. We have now provided data to define ex(939) $\mathrm{NH}_{2}$ as a new tool to further characterize the significance of GLP-1 in the regulation of fuel homeostasis in humans.

Physiological postprandial plasma levels of GLP-1 were reached with the low dose of GLP-1. They were comparable to peak levels achieved after oral ingestion of a high caloric glucose meal $(2,31)$. With the high dose of GLP-1, supraphysiological plasma levels of GLP-1 were obtained. We can now demonstrate that $\operatorname{ex}(9-39) \mathrm{NH}_{2}$ dose-dependently antagonizes the effects of physiological and supraphysiological amounts of GLP-1. In this context, an important finding was that already basal circulating levels of endogenous GLP-1 apparently play a role in the control of glucagon release.

Agreeing with previous studies, infusion of GLP-1 dosedependently increased plasma insulin and inhibited release of glucagon even during hyperglycemia $(7,8,10,11,32)$. Accordingly, the infusion rate of glucose had to be increased with GLP-1 to maintain physiological hyperglycemia. $\operatorname{ex}(9-39) \mathrm{NH}_{2}$ dose-dependently reduced this elevated requirement of exogenous glucose, and at the highest dosage of the GLP-1 antagonist the increase of glucose consumption induced by low-dose GLP-1 was fully abolished. In parallel, the GLP-1-induced increase of plasma insulin and the concomitant decrease of plasma glucagon were antagonized by $\operatorname{ex}(9-39) \mathrm{NH}_{2}$ in a dosedependent manner.

Recent studies with cells expressing the recombinant human (33) or rat (34) GIP receptor suggested that ex(9-39) $\mathrm{NH}_{2}$ binds with significant affinity to the GIP receptor. At the human GIP receptor, ex(9-39) $\mathrm{NH}_{2}$ inhibited GIP-induced cAMP accumulation with an $\mathrm{IC}_{50}$ of $4.5 \mu \mathrm{mol} /$ liter and, therefore, seemed to be a weak antagonist (24). In contrast, when infused in rats, doses of ex(9-39) $\mathrm{NH}_{2}$ sufficient to antagonize the insulinotropic action of exogenous GLP-1 did not alter the insulinotropic effect of exogenous $\operatorname{GIP}(27,28)$. However, in view of the proposed role of GIP in the entero-insulinar axis $(4,31)$ any possible effect of $\operatorname{ex}(9-39) \mathrm{NH}_{2}$ on GIP-stimulated insulin 


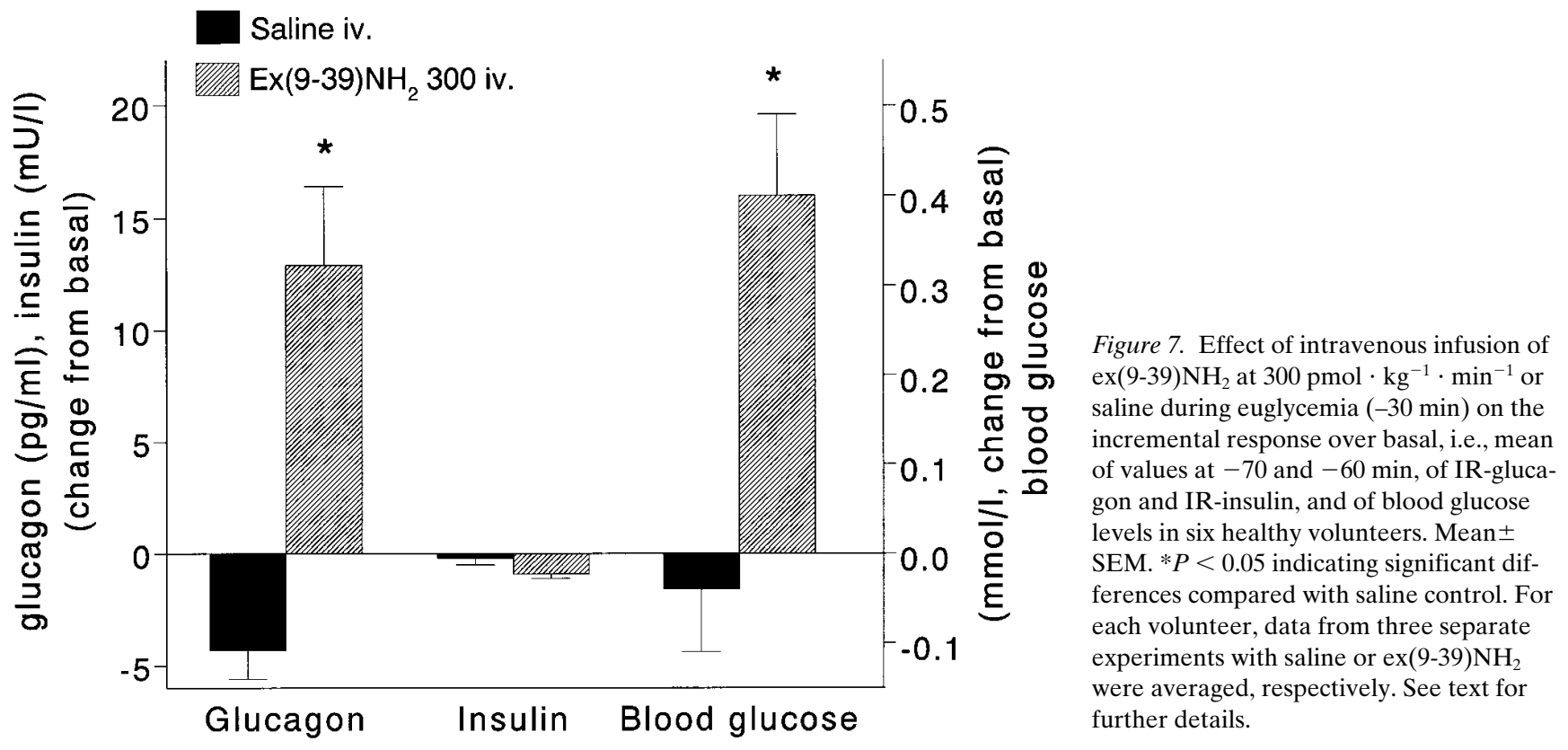

secretion had to be considered in the present study. We conclusively demonstrated that there is no such effect in humans, since a high dose of ex(9-39) $\mathrm{NH}_{2}$ that completely antagonizes the insulinotropic effect of GLP-1 does not alter the insulinotropic activity of GIP in humans $(2,11)$.

Recently, the presence of GLP-1 receptors on a subset of islet A cells and D cells has been suggested $(35,36)$. This implies that the inhibition of glucagon release by GLP-1 may be a direct effect or an indirect one via somatostatin release. In fact, exogenous GLP-1 at physiological plasma levels inhibits glucagon secretion in various species (37) including humans (7-11). An indirect suppression of glucagon by somatostatin is suggested by data revealing that GLP-1 stimulates somatostatin secretion in isolated rat and human pancreatic islets and perfused pancreas preparations (38-40). GLP-1 possesses functionally active receptors on somatostatin-secreting cells (41, 42). Therefore, glucagon secretion may be suppressed by a paracrine action induced by GLP-1, and mediated by stimulation of somatostatin secretion. Additionally, GLP-1 may influence the A cell indirectly through its stimulatory effect on the release of insulin which potently inhibits glucagon secretion (43).

Our study provides sufficient evidence that the pancreatic A cell, by whatever mechanism, is under a tonic control of GLP-1. This inhibitory influence of GLP-1 on glucagon plasma levels is dose-dependently reversed by the GLP-1 receptor antagonist. Even the lowest dose of $\operatorname{ex}(9-39) \mathrm{NH}_{2}$, which inhibits GLP-1-induced insulin secretion by $\sim 25 \%$, fully antagonized the decrease of plasma glucagon seen at the low dosage of GLP-1. Moreover, even the effects of supraphysiological plasma levels of GLP-1 on glucagon suppression were completely blocked by the antagonist. Thus, the antagonistic effect of ex(9-39) $\mathrm{NH}_{2}$ on glucagon release was clearly more potent than that on insulin release. This suggests a dominant regulatory role for gut GLP-1 on pancreatic glucagon secretion, an action which may be mediated by somatostatin.

This is further endorsed by the observation that $\operatorname{ex}(9$ -
39) $\mathrm{NH}_{2}$, infused in the euglycemic state and without exogenous GLP-1, significantly increased plasma glucagon, in spite of unaltered plasma insulin. Concomitantly, blood glucose significantly rose. Our findings in humans are supported by recent findings in baboons (29) and rats (44). A tonic regulation of an islet hormone by basal concentrations of a gut hormone indicates a possible nutrient-independent fine tuning of the endocrine pancreas, at least at the interdigestive state.

Similarly, the high dose of $\operatorname{ex}(9-39) \mathrm{NH}_{2}$ significantly increased plasma glucagon during hyperglycemia (Fig. 5 and Table II). However, considering the plasma glucagon levels before glucose infusion, hyperglycemia reduced glucagon release to a comparable extent with or without infusion of the GLP-1 antagonist. Thus, endogenous basal GLP-1 does not add to the reduction of glucagon plasma levels induced by intravenous glucose. On the other hand, the increase of glucagon plasma levels in response to the GLP-1 antagonist was maintained even during hyperglycemia and probably contributes to the lower glucose consumption during the administration of ex(939) $\mathrm{NH}_{2}$, arguably due to an increase of hepatic glucose output.

$\operatorname{ex}(9-39) \mathrm{NH}_{2}$ left unchanged the basal plasma levels of insulin at euglycemia. This is in agreement with previous studies in animals $(28,29)$. In contrast, during physiological hyperglycemia and at basal GLP-1 plasma levels, $\operatorname{ex}(9-39) \mathrm{NH}_{2}$ at the highest dose diminished insulin compared with hyperglycemia alone. Thus, even basal levels of endogenous GLP-1 exert a tonic stimulatory influence on the release of insulin from the $\mathrm{B}$ cell, but only in the presence of a simultaneous stimulation of the B cell by elevated plasma glucose. Thus, the insulinotropic action of both exogenous and endogenous GLP-1 is markedly potentiated during hyperglycemia $(4,10,31,45,46)$.

In the rat, no effect of ex(9-39) $\mathrm{NH}_{2}$ on glucose-stimulated insulin plasma levels was detected (28). However, in this study, such an effect occurred $30 \mathrm{~min}$ after onset of glucose infusion during physiological hyperglycemia. By contrast, in the study of Wang et al. (28), a short bolus of ex(9-39) $\mathrm{NH}_{2}$ together with a high intravenous glucose load was given over 2 min. There- 
fore, an unphysiological hyperglycemia could have masked the effect of $\operatorname{ex}(9-39) \mathrm{NH}_{2}$. In this study, the elevation of plasma glucagon and the decrease of plasma insulin may in concert explain the significantly diminished glucose consumption during hyperglycemia with the high dose of ex(9-39) $\mathrm{NH}_{2}$.

The two low doses of ex(9-39) $\mathrm{NH}_{2}$ at 30 and $60 \mathrm{pmol} \cdot \mathrm{kg}^{-1}$. $\mathrm{min}^{-1}$ were derived from in vivo studies in rat showing that an $\sim 10$-fold excess of the antagonist was necessary to completely block the action of exogenous GLP-1 $(27,28)$. In vitro experiments with the recombinantly expressed human GLP-1 receptor indicate a high-affinity binding of ex(9-39) $\mathrm{NH}_{2}$ to the GLP-1 receptor $\left(K_{\mathrm{d}} 1.7 \mathrm{nM}\right)$, that was not significantly different from that of GLP-1 itself (24). In contrast, the insulinotropic effects of physiological plasma levels of GLP-1 obtained with the low load of GLP-1 during hyperglycemia were inhibited by only $\sim 30 \%$ with $\operatorname{ex}(9-39) \mathrm{NH}_{2}$ at $60 \mathrm{pmol} \cdot \mathrm{kg}^{-1} \cdot \mathrm{min}^{-1}$, and a relatively high dose of $\mathrm{ex}(9-39) \mathrm{NH}_{2}$ of $300 \mathrm{pmol} \cdot \mathrm{kg}^{-1} \cdot \mathrm{min}^{-1}$, i.e., a 1,000-fold excess in relation to the GLP-1 dose, was needed to almost completely inhibit these insulinotropic effects of GLP-1. Considering the high affinity of this peptide for the human GLP-1 receptor in vitro (24), one can only speculate about a faster metabolism in plasma. We did not measure $\operatorname{ex}(9-39) \mathrm{NH}_{2}$ immunoreactivity due to lack of an available RIA. Therefore, the reason that such a large excess of ex(939) $\mathrm{NH}_{2}$ is required in humans to fully establish antagonism against GLP-1 remains unknown. Recently, another derivative of exendin-4, exendin(3-39)amide, has been shown in rats, to be up to 10-fold more potent than $\operatorname{ex}(9-39) \mathrm{NH}_{2}$ in antagonizing GLP-1-stimulated insulin release (47). However, the antagonistic potency of exendin(3-39)amide in humans has to be proven.

In summary, the present data demonstrate that ex(939) $\mathrm{NH}_{2}$ is a useful antagonist of GLP-1 in humans and is without agonistic properties. The use of GLP-1 receptor antagonists such as ex(9-39) $\mathrm{NH}_{2}$ offers the possibility to really define the role of endogenous GLP-1 in the regulation of essential gastrointestinal functions, such as gastrointestinal motility, gastric emptying, and postprandial glucose homeostasis in humans. A novel observation made here is the tonic inhibition of the pancreatic A cell by basal levels of GLP-1. Furthermore, there is even stimulation of the B cell under physiological hyperglycemia by basal GLP-1.

\section{Acknowledgments}

The excellent technical assistance of Gabriele Kraft and Michaela Junck is gratefully appreciated. We thank Elisabeth Bothe and Elke Birkenstock for precise measurements of plasma hormones and Mrs. Maiszies for the sterile preparation of GLP-1 and ex(9-39) $\mathrm{NH}_{2}$.

This work was supported by a grant from the Deutsche Forschungsgemeinschaft.

\section{References}

1. Göke, R., H.-C. Fehmann, and B. Göke. 1991. Glucagon-like peptide1(7-36)amide is a new incretin/enterogastrone candidate. Eur. J. Clin. Invest. 21:135-144.

2. Schirra, J., M. Katschinski, C. Weidmann, T. Schäfer, U. Wank, R. Arnold, and B. Göke. 1996. Gastric emptying and release of incretin hormones after glucose ingestion in humans. J. Clin. Invest. 97:92-103.

3. Brubaker, P.L. 1991. Regulation of intestinal proglucagon-derived peptide secretion by regulatory peptides. Endocrinology. 128:3175-3182.

4. Fehmann, H.-C., R. Göke, and B. Göke. 1995. Cell and molecular biology of the incretin hormones glucagon-like peptide-I and glucose-dependent in- sulin releasing polypeptide. Endocrine Rev. 16:391-410.

5. Drucker, D.J., J. Philippe, S. Mojsov, W.L. Chick, and J.F. Habener 1987. Glucagon-like peptide I stimulates insulin gene expression and increases cyclic AMP levels in a rat islet cell line. Proc. Natl. Acad. Sci. USA. 84:34343438 .

6. Fehmann, H.-C., and J.F. Habener. 1992. Insulinotropic hormone glucagon-like peptide 1-(7-37) stimulation of proinsulin gene expression and proinsulin biosynthesis in insulinoma $\beta$ TC-1 cells. Endocrinology. 130:159-166.

7. Elahi, D., M. McAloon-Dyke, N.K. Fukagawa, G.S. Meneilly, A.L. Slater, K.L. Minaker, J.F. Habener, and D.K. Andersen. 1994. The insulinotropic actions of glucose-dependent insulinotropic peptide (GIP) and glucagonlike peptide-1 (7-37) in normal and diabetic subjects. Reg. Pept. 51:63-74.

8. Gutniak, M.K., C. Ørskov, J.J. Holst, B. Ahren, and S. Efendic. 1992. Antidiabetogenic effect of glucagon-like peptide 1 (7-36) in normal subjects and patients with diabetes mellitus. N. Engl. J. Med. 326:1316-1322.

9. Komatsu, R., T. Matsuyama, M. Namba, N. Watanabe, H. Itoh, N. Kono, and S. Tarui. 1989. Glucagonostatic and insulinotropic action of glucagon-like peptide(7-36)amide. Diabetes. 38:902-905.

10. Kreymann, B., M.A. Ghatei, G. Williams, and S.R. Bloom. 1987. Glucagon-like peptide-1 7-36: a physiological incretin in man. Lancet. 2:1300-1305.

11. Nauck, M.A., M.M. Heimesaat, C. Ørskov, J.J. Holst, R. Ebert, and W. Creutzfeldt. 1993. Preserved incretin activity of glucagon-like peptide 1 [7-36 amide] but not of synthetic human gastric inhibitory polypeptide in patients with type-2 diabetes mellitus. J. Clin. Invest. 91:301-307.

12. Schirra, J., P. Kuwert, U. Wank, P. Leicht, R. Arnold, B. Göke, and M. Katschinski. 1997. Differential effects of subcutaneous GLP-1 on gastric emptying, antroduodenal motility, and pancreatic function in man. Proc. Assoc. Am. Physicians. 109:84-97.

13. D'Alessio, D.A., R.L. Brigeon, and J.W. Ensinck. 1995. Enteral enhancement of glucose disposition by both insulin-dependent and insulin-independent processes. A physiological role of glucagon-like peptide I. Diabetes. 44: 1433-1437.

14. D'Alessio, D.A., S.E. Kahn, C.R. Leusner, and J.W. Ensinck. 1994. Glucagon-like peptide 1 enhances glucose tolerance both by stimulation of insulin release and by increasing insulin-independent glucose disposal. J. Clin. Invest. 93:263-266.

15. Schirra, J., P. Leicht, P. Hildebrand, C. Beglinger, R. Arnold, B. Göke, and M. Katschinski. 1998. Mechanism of the antidiabetic action of subcutaneous GLP-1 in NIDDM. J. Endocrinol. 156:177-186.

16. Schirra, J., U. Wank, P. Houck, B. Göke, and M. Katschinski. 1996. Effects of GLP-1 on human antro-pyloro-duodenal motility. Gastroenterology. 110:A1116. (Abstr.)

17. Wettergren, A., H. Petersen, C. Ørskov, J. Christiansen, S.P. Sheikh, and J.J. Holst. 1994. Glucagon-like peptide-1 7-36 amide and peptide YY from the L-cell of the ileal mucosa are potent inhibitors of vagally induced gastric acid secretion in man. Scand. J. Gastroenterol. 29:501-505.

18. O'Halloran, D.J., G.C. Nikou, B. Kreymann, M.A. Gathei, and S.R. Bloom. 1990. Glucagon-like peptide-1 (7-36)- $\mathrm{NH}_{2}$ : a physiological inhibitor of gastric acid secretion in man. J. Endocrinol. 126:169-173.

19. Schjoldager, B.T.G., P.E. Mortensen, J. Christiansen, C. Ørskov, and J.J. Holst. 1989. GLP-1 (glucagon-like peptide 1) and truncated GLP-1, fragments of human proglucagon, inhibit gastric acid secretion in humans. Dig. Dis. Sci. 34:703-708.

20. Gutzwiller, J.-P., B. Göke, J. Drewe, S. Ketterer, D. Handschin, P. Hildebrand, R. Winterhalder, D. Conen, and C. Beglinger. 1997. Glucagon-like peptide-1 is a physiologic regulator of food intake in humans. Gastroenterology. 112:A1153. (Abstr.)

21. Göke, R., H.-C. Fehmann, T. Linn, H. Schmidt, M. Krause, J. Eng, and B. Göke. 1993. Exendin-4 is a high potency agonist and truncated exendin-(9-39)amide an antagonist at the glucagon-like peptide 1-(7-36)-amide receptor of insulin-secreting $\beta$-cells. J. Biol. Chem. 268:19650-19655.

22. Rai, A., G. Singh, R. Raffaniello, J. Eng, and J.-P. Raufman. 1990. Actions of Helodermatidae venom peptides and mammalian glucagon-like peptides on gastric chief cells. Am. J. Physiol. 265:G118-G125.

23. Raufman, J.-P., L. Singh, G. Singh, and J. Eng. 1992. Truncated glucagon-like peptide-1 interacts with exendin receptors on dispersed acini from guinea pig pancreas. J. Biol. Chem. 267:21432-21437.

24. Thorens, B., A. Porret, L. Bühler, S.-P. Deng, P. Morrel, and C. Widmann. 1993. Cloning and functional expression of the human islet GLP-1 receptor: demonstration that exendin-4 is an agonist and exendin(9-39) an antagonist of the receptor. Diabetes. 42:1678-1682.

25. Tang-Christensen, M., P.J. Larsen, R. Göke, A. Fink-Jensen, D.S. Jessop, M. Moller, and S. Sheikh. 1996. Central administration of GLP-1-(7-36)amide inhibits food and water intake in rats. Am. J. Physiol. 271:R848-R856.

26. Turton, M.D., D. Oshea, I. Gunn, S.A. Beak, C.M.B. Edwards, K. Meeran, S.J. Choi, G.M. Taylor, M.M. Heath, P.D. Lambert, et al. 1996. A role for glucagon-like peptide-1 in the central regulation of feeding. Nature. 379:69-72.

27. Kolligs, F., H.-C. Fehmann, R. Göke, and B. Göke. 1995. Reduction of the incretin effect in rats by the glucagon-like peptide 1 receptor antagonist exendin(9-39)amide. Diabetes. 44:16-19.

28. Wang, Z., R.M. Wang, A.A. Owji, D.M. Smith, M.A. Ghatei, and S.R. Bloom. 1995. Glucagon-like peptide-1 is a physiological incretin in rat. J. Clin. 
Invest. 95:417-421.

29. D'Alessio, D.A., R. Vogel, R. Prigeon, E. Laschansky, D. Koerker, J. Eng, and J.W. Ensinck. 1996. Elimination of the action of glucagon-like peptide 1 causes an impairment of glucose tolerance after nutrient ingestion by healthy baboons. J. Clin. Invest. 97:133-138.

30. DeFronzo, R.A., J.D. Tobin, and R. Andres. 1979. Glucose clamp technique: a method for quantifying insulin secretion and resistance. Am. J. Physiol. 237:E214-E223.

31. Nauck, M.A., E. Bartels, C. Ørskov, R. Ebert, and W. Creutzfeldt. 1993. Additive insulinotropic effects of exogenous synthetic human gastric inhibitory polypeptide and glucagon-like peptide-1-(7-36)amide infused at near-physiological insulinotropic hormone and glucose concentrations. J. Clin. Endocrinol. Metab. 76:912-917.

32. Nathan, D.M., E. Schreiber, H. Fogel, S. Mojsov, and J.F. Habener. 1992. Insulinotropic action of glucagonlike peptide-1-(7-37) in diabetic and nondiabetic subjects. Diabetes Care. 15:270-276.

33. Gremlich, S., A. Porret, E.H. Hani, D. Cherif, N. Vionnet, P. Froguel, and B. Thorens. 1995. Cloning, functional expression, and chromosomal localization of the human pancreatic islet glucose-dependent insulinotropic polypeptide receptor. Diabetes. 44:1202-1208.

34. Wheeler, M.B., R.W. Gelling, C.H.S. McIntosh, J. Georgiou, J.C. Brown, and R.A. Pederson. 1995. Functional expression of the rat pancreatic islet glucose-dependent insulinotropic polypeptide receptor: ligand binding and intracellular signaling properties. Endocrinology. 136:4629-4639.

35. Ding, W.-G., E. Renström, P. Rorsman, K. Buschard, and J. Gromada. 1997. Glucagon-like peptide I and glucose-dependent insulinotropic polypeptide stimulate $\mathrm{Ca}^{2+}$-induced secretion in rat $\alpha$-cells by a protein kinase A-mediated mechanism. Diabetes. 46:792-800.

36. Heller, R.S., T.J. Kieffer, and F.F. Habener. 1997. Insulinotropic glucagon-like peptide I receptor expression in glucagon-producing $\alpha$-cells of the rat endocrine pancreas. Diabetes. 46:785-791.

37. Holst, J.J., and C. Ørskov. 1996. Glucagon and other proglucagonderived peptides. In Gut Peptides: Biochemistry and Physiology. J.H. Walsh and G.J. Dockray, editors. Raven Press, New York. 305-340.

38. Fehmann, H.-C., B.J. Hering, M.J. Wolf, H. Brandhorst, D. Brandhorst, R.G. Bretzel, K. Federlin, and B. Göke. 1995. The effects of glucagon-like peptide-I (GLP-I) on hormone secretion from isolated human pancreatic islets. Pancreas. 11:196-200.

39. Heller, R.S., and G.W. Aponte. 1995. Intraislet regulation of hormone secretion by glucagon-like peptide-1-(7-36)amide. Am. J. Physiol. 269:G852G860.

40. Schmid, R., V. Schusdziarra, R. Aulehner, N. Weigert, and M. Classen. 1990. Comparison of GLP-1(7-36)amide and GIP on release of somatostatin like immunoreactivity and insulin from the isolated rat pancreas. Z. Gastroenterol. 28:280-284.

41. Fehmann, H.-C., and J.F. Habener. 1991. Functional receptors for insulinotropic hormone glucagon-like peptide-1(7-37) on a somatostatin secreting cell line. FEBS Lett. 279:335-340.

42. Gros, L., B. Thorens, D. Bataille, and A. Kervran. 1993. Glucagon-like peptide-1(7-36)amide, oxyntomodulin, and glucagon interact with a common receptor in a somatostatin-secreting cell line. Endocrinology. 133:631-638.

43. Maryama, H., M. Tominaga, G. Bolli, L. Orci, and R.H. Unger. 1985. The alpha cell response to glucose change during perfusion of anti-insulin serum in pancreas isolated from normal rats. Diabetologia. 28:836-840.

44. Montrose-Rafizadeh, C., J. Eng, Y. Wang, N. Grieg, and J.M. Egan. 1996. Elimination of GLP-1 action in vivo by a new antagonist of GLP-1 receptor, exendin-4(3-39). Reg. Pept. 64:131. (Abstr.)

45. Göke, R., B. Wagner, H.-C. Fehmann, and B. Göke. 1993. Glucose-dependency of the insulin-stimulatory effect of glucagon-like peptide-1(7-36)amide on the rat pancreas. Res. Exp. Med. 193:97-103.

46. Holz, I.V.G.G., W.M. Kuhtreiber, and J.F. Habener. 1993. Pancreatic $\beta$-cells are rendered glucose-competent by the insulinotropic hormone glucagon-like peptide-I(7-37). Nature. 361:362-365.

47. Montrose-Rafizadeh, C., H. Yang, B.D. Rodgers, A. Beday, L.A Pritchette, and J. Eng. 1997. High potency antagonist of the pancreatic glucagon-like peptide-1 receptor. J. Biol. Chem. 272:21201-21206. 